\title{
How Innovation Influences on Export Performance: A Configuration Approach for Emerging Economies
}

\author{
Jorge Heredia ${ }^{1 *}$, Alejandro Flores ${ }^{1}$, Walter Heredia ${ }^{1}$, Rocío Arango ${ }^{1}$, Lisbeth Medina ${ }^{1}$
}

\begin{abstract}
This study examines innovation on export performance under competitive strategies, institutional factors and marketing capability. We collect the information from 201 firms through surveys of four countries: Brazil, Mexico, Chile, and Peru, and we use a novel method approach (qualitative comparative analysis) to analyze how these antecedents combined to lead to the export performance. We found that the technological capability degree depends on the export market. In developed markets, firms need low technological capability, contrary when firms export to developing countries firms needs to develop high degree of technological capability. Besides, the technological capability needs to configure with implementation of strategies depends on institutional factors and marketing capability.
\end{abstract}

Keywords: Export performance; technological capability; cost strategy; differentiation strategy; qualitative comparative analysis; emerging economy

Submitted: April 27, 2019 / Approved: November $8^{\text {th }}, 2019$

\section{Introduction}

Until now, we have known or deepened the study of the external, internal, and institutional determinants of innovation (Heredia Pérez, Geldes, Kunc, \& Flores, 2018). Studies in developed countries determine that technology transfer and the existence of startups increase export performance of the country level (DiPietro \& Anoruo, 2006). Studies in the UK and Germany determine that innovation has a significant positive effect on companies' export performance (Love \& Roper, 2015; Roper \& Love, 2002). Other studies in Italy on high-tech companies have determined internal factors such as R\&D employees, $\mathrm{R} \& \mathrm{D}$ partners, and product innovation has a positive effect on export performance (D'Angelo, 2012). Likewise, other authors complement the study by identifying internal resources that increase export performance such as skills, leadership and people management, $R \& D$, capital and equipment investment, domestic financing, design, intellectual property management, leadership, and strategy (Love \& Roper, 2015). Besides, external factors increase export performance as an increase in access to knowledge (Love \& Roper, 2015). However, previous studies do not consider how does the effect of technological capability (innovation) modified under institutional factors, competitive strategies, and the export destination. The mentioned above could require to modified the level of technological capability. Also, in Latin America as an emerging economy, researchers did not study the effect of technological capability on export performance.

The study of export in the international business, marketing, and global strategy has been influential in the increase of commercial transactions between countries (Sousa, Martinez \& Coelho, 2008; Aulakh, Kotabe \& Teegen, 2000; Carneiro, Rocha \& Ferreira, 2011; Yong Gao, \& Kotabe, 2010). Export researches in emerging economies are growing fields (Yong et al., 2010; Aulakh et al., 2000). The export strategy is one of the fastest mechanisms to open new markets, especially in medium-sized enterprises and emerging economies (Yong et al., 2010; Peng, Wang and Jiang, 2008; Peng, Sun, Pinkham, \& Chen (2009).

Some studies have presented contradictory relations of the influence of variables on export performance, because of the different conditions of each review, in the marketing and international business field (Sousa et al.,2008; Leonidou, Katsikeas, \& Coudonaris, 2010). Several studies have used the resources and capabilities view to successfully explain a high export performance (Homburg, Krohmera, \& Workman, 2004). Few studies have utilized institutional variables as essential factors of export performance, although it is a crucial variable (Yong et al., 2010; Peng et al., 2008; Peng et al., 2009).

Therefore, we explain the study of the innovation (technological capability) with the implementation of competitive strategies to achieve an excellent export performance in emerging economies with external and internal variables, such as institutional factors and marketing capability). We use the strategic tripod approach, focusing on institutional and firm's capabilities. In our study, we use a novel method, the fuzzy set qualitative comparative analysis (FsQCA), and we answer the following research questions: i) how innovation (technological capability) configured under firm and institutional view, and competitive strategies increase export performance

As a theoretical contribution, we show that firms use a high or low innovation (technological capability) to achieve a great export performance depending on the institution's and firm's variables, export destination dependence, and competitive strategies.

This research is structured as follows: it begins by providing a theoretical background of the outcome and antecedents. Next, we describe the outcome and antecedent's measurement and the FsQCA method

1) Universidad del Pacífico, Perú

${ }^{*}$ Corresponding author: ja.herediap@up.edu.pe 
used to determine which configurations lead to high export performance. Finally, we examine the results, conclusions, implications, and the value of this research for future studies.

\section{TheoreticalR Background}

Strategy tripod and export performance. Many research studies the relations of different variables on export performance (Katsikeas, Leonidou, \& Morgan, 2000; Dhanaraj \& Beamish, 2003; Leonidou et al., 2010). However, there are several contradictory results and limitations of the research conditions (Stoian, Rialp, \& Rialp, 2010; Dhanaraj \& Beamish, 2003; Katsikeas et al., 2000). These contradictory results are because studies usually focus on methods that analyze a single relationship between the independent variable and the dependent variable, without considering the mutual relationship between all variables and the dependent variable (Chang, Chang, Chi, Chen, \& Deng , 2012). So, we will use a novel FsQCA method studied in previous studies, for example, Chen, Li \& Fan (2018), and the strategy tripod approach studied in previous studies (Heredia Pérez, Kunc, Durst, Flores, \& Geldes, 2018; Heredia, Flores, Geldes \& Heredia, 2017) to explain export performance in a holistic way.

We will use variables based on the institutional view (Peng et al., 2008) and firm view (Barney, 1991) to explain the use of strategies in the export performance. We consider the local effect of institutions and the institutional distance variables as institutional view, and we use marketing and technological capabilities as firms view. Also, we will use the export destination dependence and two strategies (cost and differentiation strategies) how variables that explain the export performance. According to the methodology (FsQCA) we will call "antecedents" instead of "variables" to name the variables that influence on export performance.

Now, we will explain the theory of the relation between each antecedent and export performance.

Competitive strategies and performance in emerging economies. The effect of strategy implementation on export performance is essential in emerging economies (Aulakh et al., 2000), where strategy failure happens more in the implementation phase than in conceptualization (Voola and O'Cass, 2010) and is evidenced in performance (Aulakh et al., 2000; Pertusa, Molina, \& Claver, 2010; Parnell, 2011; Voola \& O'Cass, 2010).

Aulakh et al. (2000) argue that in Brazil, Chile, and Mexico, cost strategies increase performance in developed countries, and differentiation strategies increase performance in developing markets. Parnell (2009) states that innovation-oriented strategies are positively associated with high performance in Peru, Mexico, and the United States. On the other hand, Mexico maintains the negative relationship between low-cost strategies and performance, while the United States maintains a positive relationship between these variables. Mainly, Peruvian firms are low-cost oriented, and Mexican firms are innovative. Parnell (2009) finds that top managers in Mexico consider their strategies to be less innovative and more cost-oriented than the average manager. In Peru, top managers also consider that their strategies are more cost-oriented than average and low managers. In the United States, there is no differentiation of the type of strategy by management type. From this, the strategy differs more between countries of emerging economies than in developed economies (Parnell, 2008). Therefore, cost and differentiation strategies are essential antecedents that we must consider in the study of export performance in emerging economies.

Moreover, Acquaah \& Ardekani (2008) show that it is remarkable the application of more than one strategy in a firm. In this study, they show empirically that the implementation of two combined strategies produces more excellent performance in the company on the implementation of a single strategy. Therefore, for our study, we will use as an antecedent of export performance, cost strategy, and differentiation strategy, and we will analyze if it is a necessity to combine these strategies to obtain high performance in exports.

Export destination dependence. Export destination dependence is measured as the ratio of export sales of a particular destination to total sales (Tookson \& Mohamad, 2010). Prasad, Ramamurthy, \& Naidy (2001) affirm that export dependence moderates the relation between export performance and marketing capabilities. Cadogan, Diamantopoulos, \& Siguaw (2002) find that the ability to use marketing depends mostly on the degree of export dependence. Prasad et al. (2001) point out that the amount of resources spent on exports is linked to reliance on exports. Therefore, in our study, we expect export destination dependence to be a relevant antecedent in export performance, that is, that export performance outcome depends on the combination of export destination dependence and other antecedents. We will define export destination dependence as a developed economy and developing the economy.

Institutional Conditions and Transitions. Regarding the institutional view, we use the local effect of institutions and institutional distance antecedents. Several researchers have analyzed the influence of institutions on export performance, and show that countries with better institutions have an excellent export performance (Bernard, Eaton, Jensen \& Kortum, 2003; Faruq, 2011; Rodrik, 1995). Moreover, studies find that institutional distance is negatively related to the company's performance (Chao \& Kumar, 2010; Gaur \& Lu, 2007). So, in our study, we will use the positive performance of institutions on the property right and the institutional distance as antecedents of export performance, and we will analyze whether these antecedents combine with other antecedents achieve the export performance.

Firm-specific Resources and Capabilities. Regarding the firm's view, we show marketing capability and technological capability as antecedents. Previous research suggests that firms with higher marketing competencies are more successful export performance than their competitors (Cavusgil \& Zou, 1994; Piercy, Kaleka, \& Katsikeas, 1998). About the technological capability (innovation), it is the transformation and absorption of technology to achieve technicaleconomic efficiency (Zawislak, Alves, Tello-Gamarra, Barbieux \& Reichert, 2012). Abereijo, Adegbite, Ilori, Adeniyi, \& Aderemi (2009) 
recommend that institutions promote technology transfer to achieve a better connection between the Science and Technology system and the firm's production. Reichert \& Zawislak (2014) find that in addition to technological capability, firms need other elements to achieve high performance. Likewise, many studies have analyzed the relationship between technological capability and export performance and have found a positive relationship (Athreye \& Kapur, 2015; Ernst, Ganiotsos, \& Mytelka, 1995; Krammer, 2016; Wang, Cao, Zhou \& Ning, 2013). Based on this analysis, in our study, we examine whether firms that achieve high export performance develops innovation (technological capability) or marketing capability as antecedents and whether they combine each other and with other antecedents.
So, based on the strategic tripod approach performed above, we find three possible configurations that lead to high export performance. a) Companies that have a high local effect of institutions (Faruq, 2011), low institutional distance (Chao \& Kumar, 2010), high marketing capability (Cavusgil \& Zou, 1994) high use of cost strategies and have as destination countries, developed economies (Aulakh et al., 2000), increase the export performance. b) Companies that have a high local effect of institutions (Faruq, 2011), low institutional distance (Chao \& Kumar, 2010), high marketing capability (Cavusgil \& Zou, 1994) use differentiation strategies and have developing economies as destination countries (Aulakh et al., 2000), increase the export performance. c) Firms that have a high local effect of institutions (Faruq, 2011), low institutional distance (Chao \& Kumar, 2010), high technological capability (Guan \& Ma, 2003) and combine more than one strategy (Acquaah \& Ardekani, 2008) increase the export performance.

Table 1. Expectations leading to Export performance

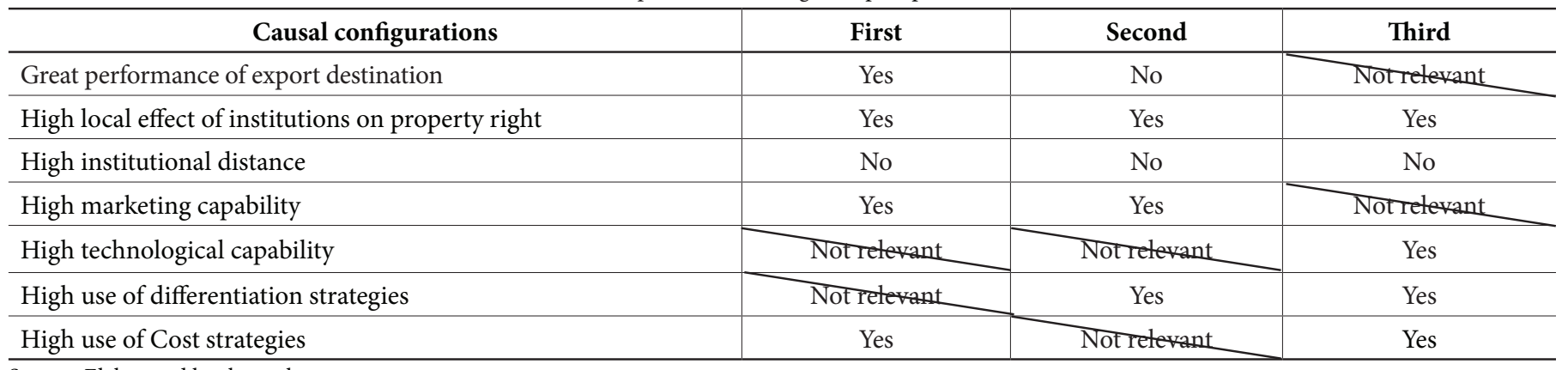

Source: Elaborated by the authors

\section{Method}

\section{Sample and Data}

Aulakh et al. (2000) affirm that the developing economies of Latin America are a particular group, given the common problems between them of inflation and external debt. We use Chile, Brazil, and Mexico data because they have a high economic growth rate in recent years, between $6 \%$ and $8 \%$ (Illescas \& Jaramillo, 2011) and has been previously studied in strategy studies in Latin American emerging economies (Aulakh et al., 2000). Also, we include Peru because their exports have overgrown in volume and profitability in recent years (Illescas \& Jaramillo, 2011), as a result of the application of trade opening policies (Awokuse, 2008), favorable market conditions such as the cost of metals (Illescas \& Jaramillo, 2011) and productivity improvements (Tulet, 2010; Illescas \& Jaramillo, 2011).
For the sample size, we consider a database of exporting companies from Chile, Brazil, Mexico, and Peru. Primary data were collected through surveys applied to managers of exporting firms from Peru, Chile, Brazil, and Mexico. Before the survey application, we validated the survey with interviews with four people in business from different countries. We realized an online survey using the Survey Monkey plan Premium software to recollect the responses. We collected the survey data between January and April 2012, and we sent a total of 4311 emails (one mail per company), addressed to executives responsible for export. A total of 262 responses, 201 were complete. Of the complete responses, $45 \%$ belong to Mexican companies, $22 \%$ to Peruvian companies, $21 \%$ to Brazilian companies and $11 \%$ to Chilean companies.

Table 2. Percentages of responses by country

\begin{tabular}{c|c|c|c|c|c|c|c}
\hline Country & $\begin{array}{c}\text { \% Responses to } \\
\text { surveys }\end{array}$ & Email submitted & Total responses & $\begin{array}{c}\text { Incomplete } \\
\text { responses }\end{array}$ & $\begin{array}{c}\text { Complete } \\
\text { responses }\end{array}$ & $\begin{array}{c}\text { \% Total responses } \\
\text { r Complete } \\
\text { responses }\end{array}$ \\
\hline Brazil & $11 \%$ & 461 & 51 & 9 & 42 & $19 \%$ \\
\hline Chile & $10 \%$ & 400 & 39 & 16 & 23 & $15 \%$ \\
\hline Mexico & $4 \%$ & 2800 & 100 & 9 & 91 & $38 \%$ & $41 \%$ \\
\hline Peru & $11 \%$ & 650 & 72 & 27 & 45 & $27 \%$ & $22 \%$ \\
\hline Total & $6 \%$ & 4311 & 262 & 61 & 201 & $100 \%$ & $100 \%$ \\
\hline
\end{tabular}

Source: Elaborated by the authors 


\section{Research Design}

FsQCA is a method based on boolean mathematics and fuzzy sets that link different paths to the same outcome (Rihoux \& Ragin, 2009). In our case, the outcome is export performance. Rihoux \& Ragin (2009) affirm that FsQCA is ideal for the study of complex variables, where different relationships complex leads to a single outcome. The asymmetric causality is a fascinating and particular characteristic of FsQCA. Asymmetric causality indicates that not necessarily the relations that led to the outcome presence, when it is combined oppositely will lead to the result absence (Schneider \& Wagemann, 2012). Also, FsQCA, unlike conventional regression analysis, is ideal for explaining a result through several theoretical explanations and which there is evidence of asymmetric causality (Brenes, 2017; Chen et al., 2018). For our study, we will use FsQCA to link seven antecedents to high export performance.

\section{Outcome and antecedents measure}

Outcome: Export performance. The export performance was measured through a seven-point scale, which evaluated export performance through the profitability of export sales compared to the three main competitors in the last three years. (1) means deficient performance and (7) means very high performance. This measure is consistent with some previous studies (Aulakh et al., 2000; Murray, Yong et al., 2010). The next part explains the measure of antecedents.

\section{Antecedents}

- Differentiation strategy and Cost strategy. Our measures are based on the measurement of one of the dimensions of cost and differentiation strategies found in previous studies, such as Aulakh et al. (2000) and Voola \& O' Cass (2010). We use two survey questions for each to measure these variables. For the differentiation strategy, the company was asked, whether it agreed or not, always to be the first to market a new product in the last three years. For the cost strategy, the company was asked, whether it agreed or not, to invest mainly in large projects to achieve economies of scale in the last three years. To see a descriptive tabulate of these antecedents, please see table 3.

- Export destination dependence. Our export destination dependence variable was measured according to the classification of developing and developed countries by Aulakh et al. (2000). The variable created was a dummy variable, where $(0)$ meant that the destination economy was a developing country, and (1) if the destination economy was a developed country. Of the total number of firms surveyed, $69 \%$ exported to developed economies and $31 \%$ to developing economies (see table 3 ).

- Institutional Conditions and Transitions. This section presents the measures of the institutional antecedent: Institutional distance and local effect of institutions. To measure institutional distance, we used the concept of institutional distance in the normative used by Chao \& Kumar (2010). In the survey, the company was asked about the perception of institutional differences between the export home country and the export destination dependence (measured according to profitability in the last three years) about regulations on customs regulations. Moreover, to measure the local effect of institutions, we used one of the three institutional dimensions used by Faruq (2011): property rights. In the survey, the company answered whether the performance was negative or positive of local institutions (public and private) of the property right on the export activity of their company in the last three years. To see a descriptive tabulate of these antecedents, please see table 3.

- Firm-specific Resources and Capabilities. This section presents the measures of the antecedents that are related to the characteristics of firms: marketing capability and technological capability. Conant, Mokwa \& Varadarajan, (1990) and Desarbo et al. (2005) measures marketing capabilities through the knowledge of customers, competition, integration of marketing programs, skills in targeting and effectiveness of advertising programs, and cost. In our study, we use the effectiveness of advertising programs as a measure of marketing capability. In the questionnaire, the company was asked how well or poorly they believe that their company carries effective promotion and advertising programs compared to the three main competitors. Technological capability. In the questionnaire, the company was asked how well or poorly they believe that their company can predict technological changes in the industry compared to the three main competitors. We consider this variable as a proxy of innovation, because it allow firms to scan the environment and make the fit with the competitive strategies and firm and institutional variables to increase export performance (Dobni \& Luffman, 2003). To see a descriptive tabulate of these antecedents, please see table 3.

Table 3. Descriptive indicators

\begin{tabular}{l|c|c|c|c|c}
\hline Variable & Observations & Mean & Standard deviation & Minimum $^{<?>}$ & Maximum $^{<?>}$ \\
\hline Export performance & 201 & 4.06 & 1.45 & 1 & 7 \\
\hline Destination economy dependence & 201 & 0.74 & 0.44 & 0 & 1 \\
\hline Local effect of institutions on property right & 201 & 4.90 & 1.50 & 7 \\
\hline Institutional distance & 201 & 3.93 & 1.78 & & 7 \\
\hline Marketing capability & 200 & 4.16 & 1.64 & 1 \\
\hline Technological capability & 200 & 4.55 & 1.52 & 7 \\
\hline Use of differentiation strategies & 201 & 3.64 & 1.81 & 7 \\
\hline Use of Cost strategies & 201 & 4.07 & 1.82 & 7 \\
\hline
\end{tabular}

Source: Elaborated by the authorsCalibration

\footnotetext{
${ }^{1}$ Lowest value.

${ }^{2}$ Greatest value.
} 
It is firstly essential and vital to calibrate the antecedents and the outcome to be able to use the FsQCA method. Calibrating in FsQCA helps to understand when cases are or are not members of a category (Ragin, 2008). For our study, we used the QCA principles (Ragin, 2008; Schneider \& Wagemann, 2012) to calibrate. We used the direct method of calibration, we divide into four intervals the antecedents and the outcome, taking each one as extremes to the values between $0,0,05,0,5,0,95$ and 1 . The values $0,05,0,5,0,95$ represent the not full membership, the crossing point and the full membership (Ragin, 2008). We show the calibration in Table 4.

Table 4. Calibrations

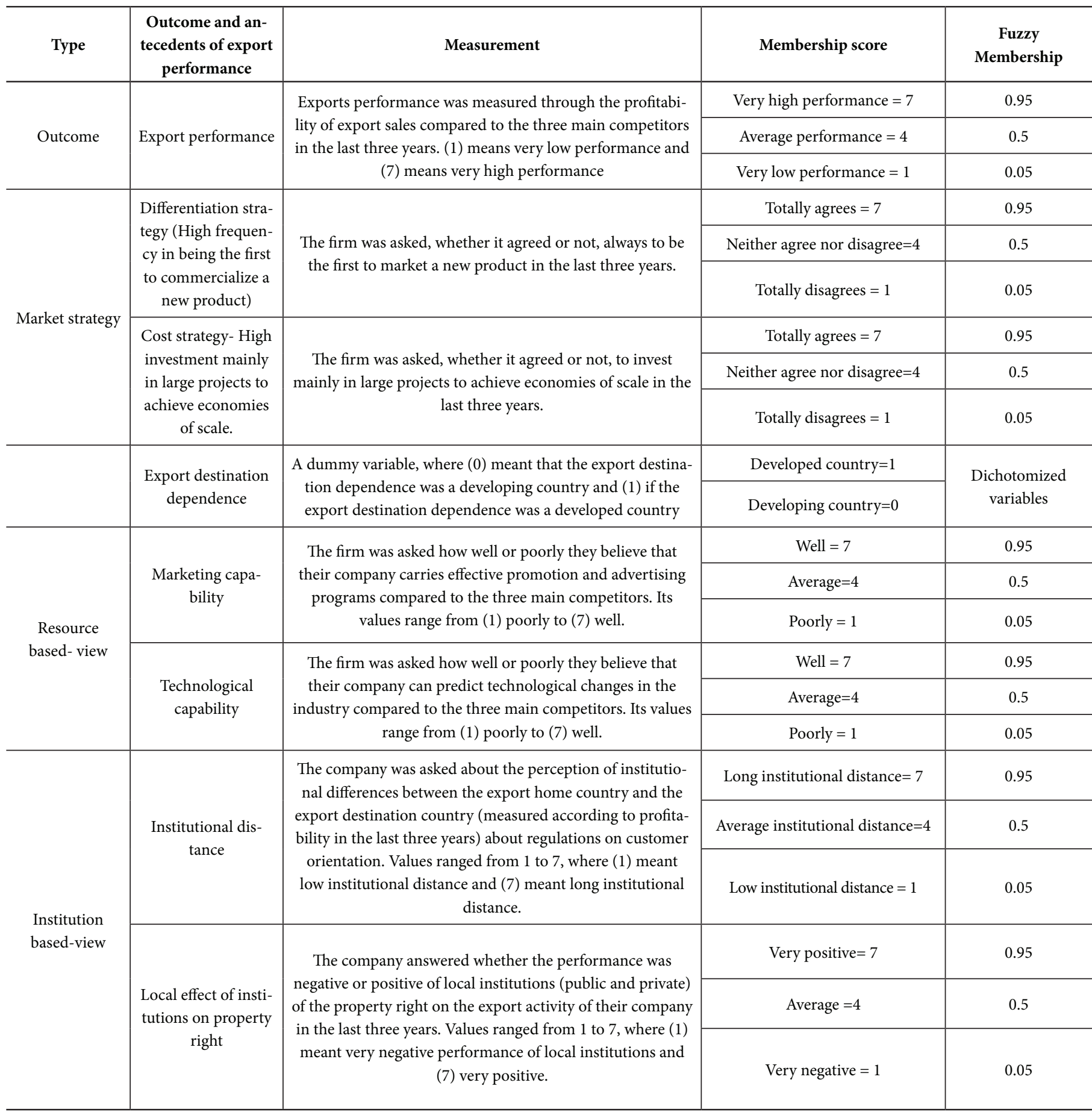

Source: Elaborated by the authors 


\section{Coverage and Consistency}

FsQCA requires to analyze the consistency and coverage of the model to know representative models, supporting the researcher to select a correct FsQCA model (Brenes, 2017; Chen et al., 2018). These measures are different from the measures of significance used in other methods, such as linear regressions. Consistency measures the degree of deviation of data from a whole subset, which is represented by a numerical value. Coverage measures the degree of explanation of outcome through antecedents (Schneider \& Wagemann, 2012). Consistency does have a minimum threshold, but coverage does not have a minimum threshold, because even models with low coverage could be of great interest for the explanation of an outcome (Schneider \& Wagemann, 2012). We set consistency values higher than 0.8 and coverage values between 0.2 and 0.6 , values that are by other studies such as Brenes (2017).

\section{Results and discussion}

Our results (see table 5) presented differences with export performance expectations (see table 1). The first difference is that even with a high institutional distance, the company can have an excellent export performance. The second difference is that the company does not necessarily apply differentiation strategies when exporting to a developing country; we observe that in configuration 2, the company uses the cost strategy to export to developing countries. Finally, the third difference is that even when local institutions have a profound effect on property rights, companies can have an excellent export performance (configurations 1 and 2).

Three configurations are linked to high export performance (see table 5). The first configuration shows that if the company has as an export destination dependence a developed economy, low local performance of the institutions on property rights, independent or not if have high institutional distance, high effectiveness of advertising, and promotion programs (high marketing capability). Moreover, the company have low ability to predict technological changes in the company (low technological capability), high frequency in being the first to commercialize a product (high use of differentiation strategy) and high investment in large projects to achieve economies of scale (high use of cost strategy) will have a significant export performance.

This type of companies export products that do not need high technology to developed countries and use a lot of marketing capability. Different investigations have shown that having low costs and maintaining excellent product quality (differentiation strategy) is effective in raising profitability in mature industries (Anderson \& Zeithaml, 1984; MacMillan, Hambrick, \& Day, 1982; Spanos, Zaralis \& Ioukas, 2004). It is essential that companies entering developed countries achieve a high market share, so they need a combination of both strategies. Therefore, these type of companies combine the cost strategy and differentiation strategy using their marketing capability on a large scale to achieve the product to the final customer and achieve an excellent export performance. The company uses the differentiation strategy for export because it has a low effect of institutions on property rights of the export home country, which drives it to look for new markets where its product is protected. Besides, firms need to spend few technological capabilities, because customers in developed economies drive for price in mature markets. So, we propose the following:

Proposition 1: If the company exports to a developed economy with low local effect of the institutions, has high marketing capability, has low technological capability, and uses two strategies (the cost strategy and the differentiation strategy), independent or not if have different regulations on customer orientation, it will have a high export performance.

The second configuration shows that if the company has as an export destination dependence a developing economy, a low performance of the institutions on property rights, different regulations on customer orientation (high institutional distance), low effectiveness of advertising, and promotion programs (low marketing capability). Moreover, the company has high ability to predict technological changes in the company (high technological capability), low frequency in being the first to commercialize a product (low use of differentiation strategy) and high investment in large projects to achieve economies of scale (high use of cost strategy).

This configuration is for companies that seek to reduce their cost through large scale production, the success of that strategy depends on, principaly, the adoption of the lastest technology in production, and capital allocations for new equipment and machinery (Zahra \& Covin, 1993; Desarbo, 2005). Additionally, companies that achieve cost leadership positions focus on refining their existing products rather than new models (Dess \& Davis, 1984; Zahra \& Covin, 1993). Therefore, since those companies focus on the process of the existing products, they tend not to consider essential to carry effective promotions and advertising programs (Zahra \& Covin, 1993; Buzzell \& Gale, 1987). The cost strategies tend to be used for companies that operate in context of poor local institutions of property rights since technologies of production are difficult to imitate by competitors (Frances, 2006) what at the same time does not encourage to use differentiation strategies. This strategy is further intensified if its exports go mostly to developing countries where the level of institutionality is low (Subramaniam, 2015). Also, a high institutional distance for firms that export to developing countries translates into export to countries with weak regulations to consumer due to the low degree of institutional on property rights in developing countries (Subramaniam, 2015). Finally, contrary to the first configuration, firms need to spend high technological capability to increase export performance because customers in developing countries are more sensitive to novelty.This context facilitates the export and ensures the success of the market strategy that is being used.

From the above, we find that technological capability is necessary to combine with the six antecedents of the strategy tripod to achieve export performance in developing markets. Therefore, we propose the following: 
Proposition 2: If the company exports to a developing economy with low local effect of the institutions, maintain a high institutional distance from the destination country, has low marketing capability, has high technological capability, and just uses one strategy (uses the cost strategy and does not use the differentiation strategy) it will have a high export performance.

The third configuration reinforces the relation of high technological capability is necessary condition to increase export performance when firms dependence on developing markets. Also, the third configuration shows that firm's technological capability needs to be combined with a high performance of the local institutions on property rights, different regulations on customer orientation (high institutional distance). Moreover, the company has high effectiveness of advertising and promotion programs (high marketing capability), high frequency in being the first to commercialize a product (high use of differentiation strategy) and high investment in large projects to achieve economies of scale (high use of cost strategy) will have a high export performance.

These are types of firms that have an excellent institutional reputation in the sale of final products for having a high local effect of institutions on property rights and require good marketing skills to reach the product to the final customer of the destination economy. Marketing capabilities support the company to harness its technological capabilities and implementing effective marketing programs. These companies use cost strategy and differentiation strategy for higher quality, better service, and lower cost to export in developing economies. Studies affirm that in emerging economies, companies that combine cost and differentiation strategy obtain more significant benefits compared to companies that apply only one strategy (Acquaah \& Ardekani, 2008). We show that the combination of strategies works well in combination with marketing capability and technological capability. Also, unlike studies that show that the institutional distance negatively affects the performance of the company (Chao \& Kumar, 2010; Gaur \& Lu, 2007), we show that even at a high institutional distance this kind of firm achieves a high export performance. The above happens because we observe that the company uses high marketing capabilities to break the barrier of institutional distance from customer orientation, i.e., the marketing capability improves the uncertainty in the difference of consumer's regulations between the export home country and the export destination country. Additionally, Khanna, Palepu, \& Sinha (2005) affirm that emerging economies usually have institutional voids, which explains that the export home country does not have complications about the regulations of the market of the export destination country and thus achieve greater success here through a high export performance. So, we propose the following:

Proposition 3: If the company exports to a developing economy with a high local effect of the institutions, has different regulations on customer orientation, has high marketing capability, has high technological capability, and uses two strategies (the cost strategy and the differentiation strategy) it will have a high export performance.

Table 5. Configurations leading to Export performance

\begin{tabular}{l|c|c|c}
\hline Causal configurations & First & Second & No \\
\hline Export destination dependence (Yes= Developed country=1, No=Developing country) & Yes & No & No \\
\hline High local effect of institutions on property rights & No & Yes \\
\hline High institutional distance & Not relevant & Yes \\
\hline High marketing capability & Yes & No & Yes \\
\hline High technological capability & No & No \\
\hline High use of differentiation strategies & Yes & Yes \\
\hline High use of Cost strategies & Yes & 0.06 \\
\hline Raw coverage & 0.20 & 0.03 \\
\hline Unique coverage & 0.20 & 0.08 \\
\hline Consistency & 0.90 & 0.97 \\
\hline Solution coverage & & 0.04 \\
\hline Solution consistency & & 0.92 \\
\hline
\end{tabular}

Source: Elaborated by the authors

\section{Conclusion and implications}

Conclusion. Our study explores the configurations that lead to a great export performance in Brazil, Mexico, Peru, and Chile using FsQCA, an innovative non-linear methodology that explains that several causal paths lead to an equifinal result for our study, export performance. To have a holistic perspective, we use the institutions and firms capabilities of the strategy tripod to classify the antecedents of export performance. We use marketing capability and technological capability as the firm's antecedents. Also, we use the local effect of the institutions and the institutional distance as institutional antecedents. Likewise, we consider the export destination dependence (Prasad et al., 2001; Tookson \& Mohamad, 2010) and the differentiation and cost costs as antecedents of export performance. 
The results show that firms are taking into account the export destination dependence and combine the use of strategy with at least an institutional antecedent and a firm antecedent to achieve an excellent export performance.

The first configuration shows that when low institutions perform on a property right, the company achieves a great export performance, combining differentiation and cost strategies with marketing capability. Interesting, firms need to spend low in the technological capability to catch customers in developed countries.

However, when the firms have an export destination in developing countries, is necessary to increase technological capability. The mentioned before is supported for the second and third configurations. Besides the second configuration shows that companies that seek to reduce their cost through large scale production choose to increment the level of automation of plants and facilities in order to refine their existing products rather than new models so that it is not necessary for firms to count with marketing capabilities. On the other side, the context of poor local institutions of property rights encourages companies to adopt cost strategy due to technology production is difficult to imitate. Also, the success of cost strategy it much more likely when the export is directed to a country with poor regulation on consumer.

Finally, the third configuration shows that before a great performance of the institutions on the property right and a great difference between the regulation of orientation to the client between the home country and the destination country, the company achieves a great export performance, combining the technological and marketing capability, with the use of differentiation and cost strategies. The export destination dependence is essential to achieve a great export performance.

The added value of our study is that, by analyzing different combinations of antecedents with a single result, we have a more refined, holistic, and simulated analysis of the antecedents of export performance.

Theoretical Contributions. We extend the previous studies on export performance through the strategy tripod (specifically, through institutional and firm variables) and FsQCA and explaining the effectiveness of the combinations of antecedents that drive an excellent export performance.

Until now, we found too much research on the positive effect of technological capability on export performance. However, they do not show how vary the level of technological capability under institutional factors and market destinations. Our first contribution shows firms need to spend less of technological capability in developed markets destination and high degree of technological capability in developing countries destination.

Aulakh et al. (2000) argue that the cost strategy achieves better results in developed countries. They argue that companies in emerging economies that compete with these markets have fewer advantages over human, financial, and technological resources, innovative products, and established brands of more developed countries. Also, consumer perceptions of these markets are more in line with low-cost products. Our second contribution is shown in the first configuration. We affirm that firms that export to a more developed economy achieve high performance, not only using the cost strategy but also using the differentiation strategy. Low performance of institutions over property right not encourage competition to have stable, innovative products and established brands, achieving the export firm has a market space to compete. The company uses effective marketing programs to support the application of differentiation strategy.

Besides, Aulakh et al. (2000) state that the differentiation strategy achieves excellent results in developing country markets. Consumers in developing countries perceive foreign products (regardless of where products come from) as better quality products and would be willing to pay a higher cost (Aulakh et al. 2000; Hulland, Todino \& Lecraw, 1996). Our third contribution is shown in the second and third configuration where we affirm that the company can use the cost strategy (second configuration) or both strategies (second and third configuration) and achieve a great export performance for the additional factors that condition the use of each strategy. For the second configuration, we would expect companies in developing countries to be less competitive and maintain lower established brands (Aulakh et al. 2000); however, considering that there is a low performance of local institutions on property right that protects innovative products and brands, exporting companies will not use the differentiation strategy. On the contrary, they will use cost strategies based on their technological capability to achieve lower costs. In the third configuration, we expect firms in developing countries to be less competitive and maintain lower established brands (Aulakh et al. 2000). Contrary to expectations, the companies are in an institutional environment that protects property rights, institutions that protects brands and innovative products, so in addition to the cost strategy, they will use the differentiation strategy accompanied by technological and marketing capability to achieve great performance.

\section{Practical implications}

Managers take account that if they want to launch products to developed economies, they do not need to spend too much on technological capability; however if they export to developing economies they will need to spend or developed technological capability.

In the case of police makers, they will know to which specific sectors will give grants to foster technological capability. They can evaluate in a holistic way the politics to promote the exportation in developing countries.

\section{References}

Abereijo, I. O., Adegbite, S. A., Ilori, M.O., Adeniyi, A. A. \& Aderemi, H. A. (2009). Technological innovation sources and institutional supports for manufacturing small and medium enterprises in Nigeria. Journal of Technology Management \& Innovation, 4(2). https:// doi:10.4067/s0718-27242009000200007 
Acquaah, M., \& Yasai-Ardekani, M. (2008). Does the implementation of a combination competitive strategy yield incremental performance benefits? A new perspective from a transition economy in SubSaharan Africa. Journal of Business Research, 61 (4), 346-354. https:// doi:10.1016/j.jbusres.2007.06.021

Anderson, C.R., \& Zeithaml, C. P. (1984). Stage of product life cycle, business strategy, and business performance. Academy of Management Journal, 27(1), 5-24. https://doi:10.2307/255954

Athreye, S. \& Kapur, S. (2015). Capital and technology flows: Changing technology acquisition strategies in developing countries. The Handbook of Global Science, Technology, and Innovation, 191-211. http://doi:10.1002/9781118739044.ch9

Aulakh, P. S., \& Kotabe, M., \& Teegen, H. (2000). Export strategies and performance of firms from emerging economies: Evidence from Brazil, Chile, and Mexico. Academy of management Journal, 43(3), 342-361. https://doi.org/10.5465/1556399

Awokuse, T. O. (2008). Trade openness and economic growth: is growth export-led or import-led? Applied Economics, 40(2), 161173. http://doi:10.1080/00036840600749490

Barney, J. B. (1991). Firm resources and sustained competitive advantage. Journal of Management, 17(1), 99-120. http:// doi:10.1177/014920639101700108

Bernard, A., Eaton, J., Jensen, J. B., \& Kortum, S., (2003). Plants and productivity in international trade. American Economic Review, 93(4), 1268-1290. http://doi:10.1257/000282803769206296

Brenes, E. R., Ciravegna, L., \& Woodside, A. G. (2017). Constructing useful models of firms' heterogeneities in implemented strategies and performance outcomes. Industrial Marketing Management, 62, 1735. https://doi.org/10.1016/j.indmarman.2016.12.001

Buzzell, R. \& Gale B. (1987). The PIMS Principles: Linking Strategy to Performance. The Free Press, New York. https://doi.org/10.1016/00246301(89)90028-9.

Cadogan, J.W., Diamantopoulos, A. \& Siguaw, J.A. (2002). Export market-oriented activities: Their antecedents and performance consequences. Journal of International Business Studies, 33 (3), 615-626. https://doi.org/10.1057/palgrave.jibs.8491036

Carneiro, J., da Rocha, A., \& Ferreira da Silva, J. (2011). Determinants of Export Performance: a Study of Large Brazilian Manufacturing Firms. Brazilian Administration Review, 8(2), 107-132. https://doi. org/10.1590/s1807-76922011000200002

Cavusgil, S., \& Zou, S. (1994). Marketing Strategy-Performance Relationship: An Investigation of the Empirical Link in Export Market Ventures. Journal of Marketing, 58(1), 1-21. https://doi:10.2307/1252247
Chang, Y. C., Chang, H. T., Chi, H. R., Chen, M. H., \& Deng, L. L. (2012). How do established firms improve radical innovation performance? the organizational capabilities view. Technovation, 32(7-8), 441-451. https://doi.org/10.1016/j.technovation.2012.03.001

Chao, M. C. H., \& Kumar, V. (2010). The impact of institutional distance on the international diversity-performance relationship. Journal of World Business, 45(1), 93-103. https://doi.org/10.1016/j. jwb.2009.04.005

Chen, L., Li, Y., \& Fan, D. (2018). How do emerging multinationals configure political connections across institutional contexts? Global Strategy Journal, 8(3), 447-470. https://doi.org/10.1002/gsj.1187

Conant, J. S., Mokwa, M. P., \& Varadarajan, P. R. (1990). Strategic Types , Distinctive Marketing Competencies and Organizational Performance: A Multiple Measures-Based Study. Strategic Management Journal, 11(5), 365-383. https://doi.org/https://doi.org/10.1002/ smj.4250110504

D’Angelo, A. (2012). Innovation and export performance: A study of Italian high-tech SMEs. Journal of Management and Governance, 16(3), 393-423. https://doi.org/10.1007/s10997-010-9157-y

Day, G. S. (1994). The Capabilities of Market-Driven Organizations. Journal of Marketing, 58(4), 37. https://doi.org/10.2307/1251915

Desarbo, W. S., Di Benedetto, C. A., Song, M., \& Sinha, I. (2005). Revisiting The Miles And Snow Strategic Framework: Uncovering interrelationships Between Strategic Types, Capabilities, Environmental Uncertainty, And Firm Performance. Strategic Management Journal, 26(1), 47-74. https://doi.org/10.1002/smj.431

Dess, G. G., \& Davis, P. S. (1984). Porter's (1980) Generic Strategies as Determinants of Strategic Group Membership and Organizational Performance. Academy of Management Journal, 27(3), 467-488. https://doi.org/10.5465/256040

Dhanaraj, C., \& Beamish, P. W. (2003). A Resource-Based Approach to the Study of Export Performance. Journal of Small Business Management, 41(3), 242-261.

DiPietro, W. R., \& Anoruo, E. (2006). Creativity, innovation, and export performance. Journal of Policy Modeling, 28(2), 133-139. https:// doi.org/10.1016/j.jpolmod.2005.10.001

Dobni, C.B., Luffman, G., 2003. Determining the scope and impact of market orientation profiles on strategy implementation and performance. Strategic Management Journal,. 24(6), 577-585. https://doi. $\operatorname{org} / 10.1002 / \mathrm{smj} .322$

Ernst, D., Mytelka, L., \& Ganiatsos, T. (1995). Technological capabilities in the context of export-led growth. Technological Capabilities and Export Success in Asia, 5. https://doi:10.4324/9780203184226_chapter_1 
Faruq, H. A. (2011). How institutions affect export quality. Economic Systems, 35(4), 586-606. https://doi.org/10.1016/j.ecosys.2011.05.001 Francés, A. (2006). Estrategia y planes para la empresa: Con el cuadro de mando integral. M. F. Castillo (Ed.) México DF, México: Pearson Prentice Hall.

Gao, G. Y., Murray, J. Y., Kotabe, M., \& Lu, J. (2010). A “strategy tripod” perspective on export behaviors: Evidence from domestic and foreign firms based in an emerging economy. Journal of International Business Studies, 41(6), 1090-1091. https://doi.org/10.1057/jibs.2010.32

Gaur, A. S., \& Lu, J. W. (2007). Ownership strategies and survival of foreign subsidiaries: Impacts of institutional distance and experience. Journal of Management, 33(1), 84-110. https://doi. org/10.1177/0149206306295203

Guan, J., \& Ma, N. (2003). Innovative capability and export performance of Chinese firms. Technovation, 23(9), 737-747. https://doi. org/10.1016/S0166-4972(02)00013-5

Heredia Pérez, J. A., Geldes, C., \& Heredia, W. (2017). Effects of informal competition on innovation performance: the case of pacific alliance. Journal of Technology Management \& Innovation, 14(2), 22-28. https://doi.org/https://doi.org/10.4067/s0718-27242017000400003

Heredia Pérez, J. A., Geldes, C., Kunc, M. H., \& Flores, A. (2018). New approach to the innovation process in emerging economies: The manufacturing sector case in Chile and Peru. Technovation, (February), 1-21. https://doi.org/10.1016/j.technovation.2018.02.012

Heredia Pérez, J. A., Kunc, M. H., Durst, S., Flores, A., \& Geldes, C. (2018). Impact of competition from unregistered firms on R\&D investment by industrial sectors in emerging economies. Technological Forecasting and Social Change, (March), 1-12. https://doi.org/10.1016/j. techfore.2018.03.028

Homburg, C., Krohmer, H., \& Workman, J. P. (2004). A strategy implementation perspective of market orientation. Journal of Business Research, 57, 1331-1340. https://doi.org/10.1016/S01482963(03)00069-9

Hoskisson, R. E., Eden, L., Lau, C. M., \& Wright, M. (2000). Strategy in emerging economies. Academy of Management Journal. Academy of Management Journal, 43(3), 249-267. https://doi.org/https://doi. org/10.5465/1556394

Hulland, J., Todiño, H. S., \& Lecraw, D. J. (1996). Country-of-Origin Effects on Sellers' Price Premiums in Competitive Philippine Markets. Journal of International Marketing, 4(1), 57-79. https://doi. org/10.1177/1069031x9600400105

Illescas, J., \& Jaramillo, C. (2011). Export growth and diversification: the case of Peru. Policy Research Working Paper, (November). Retrieved from https://openknowledge.worldbank.org/handle/10986/3634
Katsikeas, C. S., Leonidou, L. C., \& Morgan, N. A. (2000). Firm-level export performance assessment: Review, evaluation, and development. Journal of the Academy of Marketing Science, 28(4), 493-511. https://doi.org/10.1177/0092070300284003

Khanna, T., K. G. Palepu, and Sinha J. (2005). Strategies that fit emerging markets. Harvard Business Review, 83 (6): 63-76.

Krammer, S. M. S. (2016). The role of diversification profiles and dyadic characteristics in the formation of technological alliances: Differences between exploitation and exploration in a low-tech industry. Research Policy, 45(2), 517-532. https://doi.org/10.1016/j.respol.2015.10.014

Leonidou, L. C., Katsikeas, C. S., \& Coudounaris, D. N. (2010). Five decades of business research into exporting: A bibliographic analysis. Journal of International Management, 16(1), 78-91. https://doi. org/10.1016/j.intman.2009.06.001

Love, J. H., \& Roper, S. (2015). SME innovation, exporting and growth: A review of existing evidence. International Small Business Journal: Researching Entrepreneurship, 33(1), 28-48. https://doi. org/10.1177/0266242614550190

Macmillan, I. C., Hambrick, D. C., \& Day, D. L. (1982). The product portfolio and profitability: a PIMS-based analysis of industrial-product businesses. Academy of Management Journal, 25(4), 733-755. https://doi.org/https://doi.org/10.5465/256096

Murray, J. Y., Gao, G. Y., \& Kotabe, M. (2011). Market orientation and performance of export ventures: The process through marketing capabilities and competitive advantages. Journal of the Academy of Marketing Science, 39(2), 252-269. https://doi.org/10.1007/s11747010-0195-4

Parnell, J. A. (2008). Strategy execution in emerging economies: Assessing strategic diffusion in Mexico and Peru. Management Decision, 46(9), 1277-1298. https://doi. org/10.1108/00251740810911948

Parnell, J. A. (2010). Competitive Strategy and Performance in Mexico, Peru, and the United States. Journal of CENTRUM Cathedra: The Business and Economics Research Journal, 3(2), 150-165. https://doi. org/10.7835/jcc-berj-2010-0044

Parnell, J. A. (2011). Strategic capabilities, competitive strategy, and performance among retailers in Argentina, Peru and the United States. Management Decision, 49(1), 139-155. https://doi. org/10.1108/00251741111094482

Peng, M., Sun, S., Pinkham, B., \& Chen, H. (2009). The Institution-Based View as a Third Leg for a Strategy Tripod. Academy of Management Perspectives, 23(3), 63-81. https://doi.org/10.5465/ AMP.2009.43479264 
Peng, M., Wang, D., \& Jiang, Y. (2008). An institution-based view of international business strategy: A focus on emerging economies. Journal of International Business Studies, 39(5), 920-936. https://doi. org/10.1057/palgrave.jibs.8400377

Pertusa-Ortega, E. M., Molina-Azorín, J. F., \& Claver-Cortés, E. (2010). Competitive strategy, structure and firm performance: A comparison of the resource-based view and the contingency approach. Management Decision, 48(8), 1282-1303. https://doi. org/10.1108/00251741011076799

Piercy, N. F., Kaleka, A., \& Katsikeas, C. S. (1998). Sources of competitive advantage in high performing exporting companies. Journal of World Business, 33(4), 378-393. https://doi.org/10.1016/S10909516(99)80081-9

Prasad, V. K., Ramamurthy, K., \& Naidu, G. M. (2001). The influence of internet - marketing integration on marketing competencies. Journal of International Marketing, 9(4), 82-110. https://doi.org/https:// doi.org/10.1509/jimk.9.4.82.19944

Ragin, C. C. (2008). Redesigning social inquiry: Fuzzy sets and beyond. Chicago: University of Chicago Press. https://doi.org/10.7208/ chicago/9780226702797.001.0001

Reichert, F. M., \& Zawislak, P. A. (2014). Technological capability and firm performance. Journal of Technology Management and Innovation, 9(4), 20-35. https://doi.org/10.4067/S0718-27242014000400002

Rihoux, B., and Ragin, C. C. (2009). Configurational comparative methods: Qualitative comparative analysis (QCA) and related techniques. Applied social research methods series. 51. Thousand Oaks, CA: Sage.

Rodrik, D. (1995). Getting interventions right: how South Korea and Taiwan grew rich. Economic Policy, 20, 53-97. https://doi.org/https:// doi.org/10.3386/w4964

Roper, S., \& Love, J. H. (2002). Innovation and export performance: Evidence from the UK and German manufacturing plants. Research Policy, 31(7), 1087-1102. https://doi.org/10.1016/S00487333(01)00175-5

Schneider, C. Q., \& Wagemann, C. (2012). Set-theoretic methods for the social sciences: A guide to qualitative comparative analysis. Cambridge University Press. http://dx.doi.org/10.1017/ CBO9781139004244
Sousa, C. M. P., Martínez-López, F. J., \& Coelho, F. (2008). The determinants of export performance: A review of the research in the literature between 1998 and 2005. International Journal of Management Reviews, 10(4), 343-374. https://doi.org/10.1111/j.14682370.2008.00232.x

Spanos, Y. E., Zaralis, G., \& Lioukas, S. (2004). Strategy and industry effects on profitability: Evidence from Greece. Strategic Management Journal, 25(2), 139-165. https://doi.org/10.1002/smj.369

Stoian, M. C., Rialp, A., \& Rialp, J. (2010). Export performance under the microscope: A glance through Spanish lenses. International Business Review, 20(2), 117-135. https://doi.org/https://doi.org/10.1016/j. ibusrev.2010.07.002

Subramaniam, M., Ernst, H., \& Dubiel, A. (2015). From the special issue editors: Innovations for and from emerging markets. Journal of Product Innovation Management, 32(1), 5-11. https://doi. org/10.1111/jpim.12167

Tookson, P., and Mohamad, O. (2010). Marketing Capability and Export Performance: the Moderating Effect of Export Dependence. The South East Asian Journal of Management, 4(1), 39-52. https://doi/ org/10.21002/seam.v4i1.5630

Tulet, J. C. (2010). Peru as a new major actor in latin American coffee production. Latin American Perspectives, 37(2), 133-141. https://doi. org/10.1177/0094582X09356962

Voola, R., \& O'Cass, A. (2010). Implementing competitive strategies: The role of responsive and proactive market orientations. European Journal of Marketing, 44(1-2), 245-266. https://doi. org/10.1108/03090561011008691

Wang, Y., Cao, W., Zhou, Z., \& Ning, L. (2013). Does external technology acquisition determine export performance? Evidence from Chinese manufacturing firms. International Business Review, 22(6), 1079-1091. https://doi.org/10.1016/j.ibusrev.2013.02.009

Zahra, S. A., \& Covin, J. G. (1993). Business Strategy, Technology Policy and Firm Performance. Strategic Management Journal, 14, 451478. https://doi.org/https://doi.org/10.1002/smj.4250140605

Zawislak, P. A., Alves, A. C., Tello-Gamarra, J., Barbieux, D., \& Reichert, F. M. (2012). Innovation capability: From technology development to transaction capability. Journal of Technology Management and Innovation, 7(2), 14-25. https://doi.org/10.4067/s071827242012000200002 
